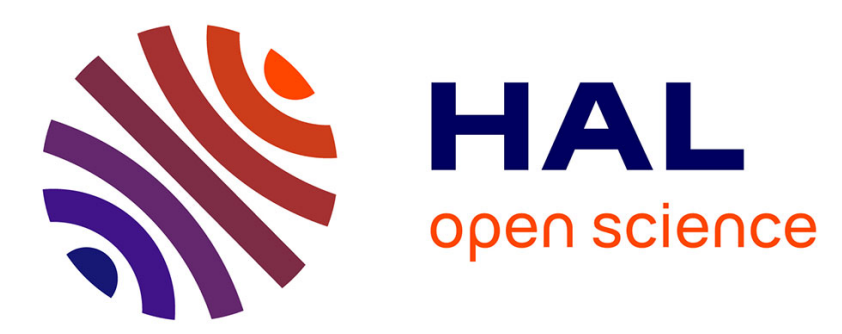

\title{
Thermal and pressure properties of amorphous polymers: relation to probe spectroscopy \\ R. Simha
}

\section{To cite this version:}

R. Simha. Thermal and pressure properties of amorphous polymers: relation to probe spectroscopy. Journal de Physique IV Proceedings, 1993, 03 (C4), pp.C4-223-C4-224. 10.1051/jp4:1993433 . jpa00251476

\section{HAL Id: jpa-00251476 https://hal.science/jpa-00251476}

Submitted on 1 Jan 1993

HAL is a multi-disciplinary open access archive for the deposit and dissemination of scientific research documents, whether they are published or not. The documents may come from teaching and research institutions in France or abroad, or from public or private research centers.
L'archive ouverte pluridisciplinaire HAL, est destinée au dépôt et à la diffusion de documents scientifiques de niveau recherche, publiés ou non, émanant des établissements d'enseignement et de recherche français ou étrangers, des laboratoires publics ou privés. 


\title{
Thermal and pressure properties of amorphous polymers: relation to probe spectroscopy
}

\author{
R. SIMHA
}

Department of Macromolecular Science, Case Western Reserve University, Cleveland, Ohio 44 106-7202, U.S.A.

\begin{abstract}
We discuss the elements of a statistical thermodynamic theory of an equilibrium melt and its corresponding quasi-equilibrium glass. It involves a lattice model with a fraction $h$ of vacancies as a measure of structural disorder. In the equilibrium melt the function $h(V, T)$ is derived by a minimization of the configurational free energy.

In the glass of specified formation history it is obtained from the experimental equation of state. The interpretation of this function as a free volume quantitiy in the frame of the lattice model results in important connections betwen thermodynamic and kinetic processes. In the present context the theory establishes correlations between the properties of the matrix and the characteristics of the o-positronium species.
\end{abstract}

The title suggests correlations between two seemingly diverse phenomena. One is the response of volume to changes in temperature, pressure, and also anisotropic stress. The other involves the response of a molecular probe, in the present case the o-positronium species, to changes in its environment, brought about by changes in the variables of state.

The purpose of this paper is to show how such correlations may come about, and to present some theoretical and experimental results. The basis is a statistical theory of the configurational thermodynamic properties of the two states in which an amorphous, i.e. molecularly disordered, polymer may exist, namely the melt or, if crosslinked, the rubbery state, and the glass. The former can be studied under thermodynamic equilibrium conditions. The glass, on the other hand, can be viewed as a quasi-equilibrium state, under sufficiently rapid experimentation, such that the slow relaxation toward equilibrium, the so-called physical aging process, remains unobservable.

Our statistical theory models the system as a lattice with sites either occupied by chain segments or vacant (holes). A reference segment, located within a cell formed by such surroundings, executes thermal motions, subject to intersegmental attractions and repulsions (1). The volume and temperature dependent fraction $h$ of vacancies is to be taken as a measure of disorder in the frame of the lattice model. In thermodynamic equilibrium, this function is uniquely derived by the minimization of the configurational free energy. In the glass, we obtain $h$ by a combination of PVT with the equations of the lattice model. The equilibrium theory has been extensively and successfully compared with the results of pressure - volume temperature measurements. Moreover, it has been generalized to multi-constituent systems. The results of the theory enable us to consider correlations with other, non-equilibrium processes. The crucial step is the interpretation of the h-function, introduced initially as a measure of structural disorder, as an excess free volume fraction, i.e., as an excess over the corresponding fraction in the abscence of vacancies. This function then forms the link to such issues as the temperature and pressure scaling of Newtonian viscosity, the corresponding scaling of visco-elastic parameters, and the linear thermo-elastic properties of a glass. Further items are the kinetics of volume relaxation on prolonged annealing, the diffusion of a probe in the matrix and finally structural probe spectroscopy. 
The question of particular concern in the present context is the connection with the results of positron spectroscopy. The natural focus is $\tau_{3}$, the mean lifetime of the o-positronium species, and $\mathrm{I}_{3}$, its intensity. If we accept the former to be related to cavity size, and the latter to the number density of cavities, then we can define a positron free volume fraction and explore its relation to the h-functions, derived from the equation of state over a range of temperatures and pressures (2). Proceeding further, we are lead to consider the following points: Given a particular value of $h$ at a specified temperature and pressure, the vacancies do not exist exclusively as single holes, but in clusters of varying multiplicity, the more so of course, the higher the temperature and thus the larger $h(3)$.

Moreover, the free volume, which defines the environment of the probe, is subject to thermal fluctuations (4). If these do not relax within a few nanoseconds, then this should also influence the $\tau_{3}$-behaviour. That is, we have to reckon with a distribution of $\tau_{3}$-values, to be confronted with an experimental average (4).

A further extension of the free volume theory concerns the thermoelastic properties of polymer glasses, so far in the linear range of deformations. On the other hand, a correlation between $\tau_{3}$ and Young's modulus has been observed experimentally (5). The results of the theory appear indeed to be in accord with such a correlation.

1/ See for a review and earlier references: Simha, R., in Frontiers of Macromolecular Science (1989) 307. Eds. Saegusa, F., Higashimura, T., Abe, A., Simha, R., Makromol. Chem., Macromol. Symp. 65 (1993) 69.

2/ Kobayashi, Y., Zheng, W., Meyer, E.F., McGervey, J. D., Jamieson, A.M., Simha, R., Macromolecules 22 (1989) 2302.

3/ Vleeshouwers, S., Kluin J., McGervey, J.D., Jamieson, A. M., Simha, R., J. Polym. Sci., Polym. Phys. 30 (1992) 1429.

4/ Robertson, R.E., Simha, R., Curro, J.G., Macromolecules 17, (1984) 911.

5/ Kobayashi, Y., unpublished. 